\title{
The Relationship Between Total Quality Management Practices and Secondary School Performance with Mediating Effect of Organizational Culture in Abu Dhabi: A Structural Equation Modeling Approach
}

\section{Khaled Sultan Alhosani}

Faculty of Management and Economics, Universiti Pendidikan Sultan Idris, Malaysia

Kamarul Bahari Yaakub

Faculty of Management and Economics, Universiti Pendidikan Sultan Idris, Malaysia

\section{Abstract}

This study aims to investigate the structural equation modeling to determine the relationship between total quality management practices and secondary school performance with mediating effect of organizational Culture in Abu Dhabi. Quantitative research design was adopted to obtained information from respondents. A total of 320 employees of school were selected as a sample through the stratified and quota random sampling technique. Data analysis using structural equation modelling was used. The results of the study indicated that significant relationship was found between total quality management practices and secondary school performance with value of -.01. The findings showed that significant relationship exist between total quality management practices and organizational culture with value of .86; significant relationship was also found between organizational culture and secondary school performance .87. Further, the findings reported that organizational culture showed complete mediation between total quality management practices and secondary school performance. This study believed that total quality management would yield good results if secondary school in Abu Dhabi make use of it to improve school performance.

Keywords: total quality management practices, organizational culture, secondary school performance, education, school

\section{Introduction}

Total Quality Management is a management terminology which organization used to improve the quality of product to meet customer satisfaction (Akgün, Ince, Imamoglu, Keskin \& oglu, 2014). As total quality management imply means totality of strategies organization can use to meet the demand of the customer. Total quality management 
is not the only the best management but a corporate philosophy that identify that business objectives and customers wants in have the same thing in common (Dhar, 2015). One of the cardinals' aims of the total quality management is that the organization should use both internal and external mechanisms to produce quality which the customer pay for. In order to be successfully in total quality management, it must be top management-driven and on maximizing efficiency and effectiveness, and promoting market dominance through improving systems and error prevention, and aligning business goals and customer wants (Sadikoglu \& Olcay, 2014).

Total quality management improve organizational the productivity of workers to produce quality of product to meet customers satisfaction (Suleman \& Gul, 2015). Therefore, organizational culture is the values, beliefs, assumption and good ways of interacting that will lead to psychological environment of an organization. Also, organization culture contains an organization expectation philosophy, vast experience as well as those values that promote good conduct among the workers. As a matter of fact, culture is based on rule and regulation, customs and share attitude which has been in existence for so long (Mahmood, Qadeer, \& Ahmed, 2015).

Hence, for schools in Abu Dhabi to meet high performance, the Irtiqaa program was introduced by the Department of Education and Knowledge in Abu Dhabi (ADEK) to address some of the problems affecting the school system. Before this program was launched, teachers employed in the system do not understand how quality takes in the school. Apart from this, the organization observed that some teachers are less committed to teaching profession which has affected overall quality of education in the country (ADEK). Because of this, Irtiqaa program has been able to provide trainees with effective techniques, traits of influential personality assessment skills that they need, and build a complete set of competencies among the teacher, given the mentor trainees a better leadership role in the future through participating in evaluation of schools, working within the Abu Dhabi emirate. Therefore, Irtiqaa program comes in to ameliorate the problems affecting secondary schools in Abu Dhabi (ADEK). Based on this useful discussion, the following objectives were formulated.

1. To determine the relationship between total quality management practices and secondary school performance in Abu Dhabi.

2. To investigate relationship between total quality management practices and organizational culture in secondary schools in Abu Dhabi.

3. To determine the relationship between organizational culture and secondary school performance in Abu Dhabi.

4. To verify whether organizational culture can mediate the relationship between total quality management practices and secondary school performance in Abu Dhabi.

Problem Statement 
The UAE's Ministry of Education (MOE) developed Education 2020 strategy, which is a series of ambitious five-year plans 2017-2021 designed to bring significant qualitative improvement in the education system, as well as curriculum revision, including teaching math and science in English, are all part of the strategy. More so, some teachers are still lacking some information about what total quality management is all about. Capacity building that will keep teachers abreast of latest information was lacking. The study also found that some teachers in the schools are yet to up-date themselves in area of getting additional qualifications. These problems do not mean that total quality management was not available in the school, but it has not yield good result as expected (Soomro \& Ahmad, 2012). This is why the Irtiqaa was inaugurated by the ministry of education to sensitize teachers on the management of quality in the school. Based on this, there is need to investigate the total quality management and secondary school performance with organizational culture as a mediating in Abu Dhabi.

Apart from the aforementioned problems, several studies investigated on the total quality management was on different areas and countries. Takes for instance, total quality and performance on workers (Joiner, 2007) total quality management and organizational culture (Gharakhani, Rahmati, Farrokhi, \& Farahmandian, 2013); total quality management in Pakistan workers (Akhtar, Zameer \& Saeed, 2014); total quality management on firms performance (Ngambi \& Nkemkiafu, 2015); quality management and organizational performance in manufacturing firms (Milanole, 2016); total quality management on organizational culture in oil management (AlDamen, 2017); organizational culture and job satisfaction (Belias \& Koustelios, 2014); organizational culture on job satisfaction (Habib, Aslam, Hussain, Yasmeen \& Ibrahim, 2014); organizational culture, teamwork and job satisfaction (Korner, Wirtz, Bengel, \& Goritz, 2015); Effect of organizational culture on construction (Arditi, Nayak, \& damci, 2017). There is still little research on the integration of total quality management on secondary school performance with organizational culture as a mediator among researchers of management. Due to lack of three variables in the study and dearth of it in UAE, it informed the researcher to examine total quality management in UAE Schools.

\section{Conceptual framework}

In the conceptual framework formulated in Figure 1. There were three variables used which include total quality management practices, organizational culture and secondary school performance. The independent variable was total quality management practices while secondary school performance represented dependent variable. The last variable was mediator which was represented by organizational culture. There were five dimensions measuring total quality management which were; school leadership, students focus, training, knowledge and process management, and strategic quality planning. For the organizational culture, four dimensions were formulated which include team orientation, communication, goal 
orientation and rules orientation. Lastly, the dimensions measuring secondary school performance were students' achievement and graduation rate. development of this conceptual framework came from the literatures of Donmez \& Toker (2017); Prajogo \& Sohal (2006); Kum, Cowden \& Karodia (2014); Sadikoglu \& Olcay (2014); Driskell, Salas, \& Hughes (2010); Bruno (2009); Ramirez (2012; Ratsameemonthon, (2015); Bruno (2009); Fine, Van Rooij, Feldman, Shalvi, Scheper, Leib, \& Cauffman. (2016); Stephen, 2016; Anticevic, Kardum, Klarin, Sindik, \& Barač, 2018; Lucky (2001). Therefore, the relationship among these variables were shown in Figure 1.

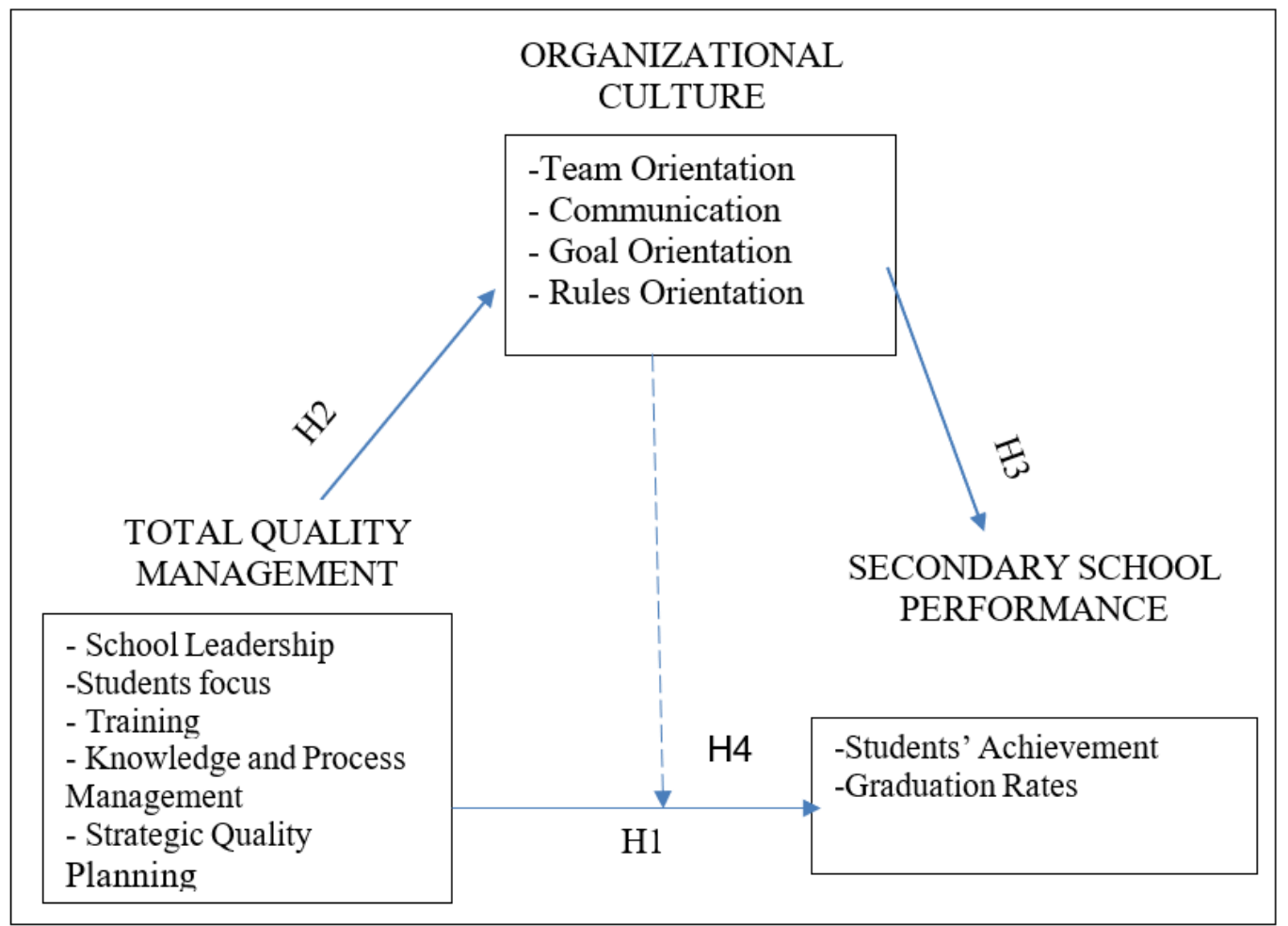

Figure 1. Conceptual framework of the study

\section{Research hypotheses}

Research hypotheses are all about making predictions about the expected results of the research work after data is obtained for analysis by the researcher (Creswell, 2017). Based on the conceptual framework depicted above, the hypotheses were stated in this ways:

H1: There will be significant relationship between total quality management practices and secondary school performance in Abu Dhabi. 
$\mathrm{H} 2$ : There will be significant relationship between total quality management practices and organizational culture in secondary schools in Abu Dhabi.

H3: There will be significant relationship between organizational culture and secondary school performance in Abu Dhabi

$\mathrm{H} 4$ : There will be mediating role of organizational culture on the relationship between total quality management practices and secondary school performance in Abu Dhabi.

Conceptualizing Total Quality Management (Total Quality Management)

Total quality management is the organizational efforts to install and develop a conducive climate in which an organization continuously improve and deliver high quality product that will meet the satisfaction of customers (hendricks \& singhal, 2001). Total quality management is the endless process of identify and reducing errors in manufacturing. Total quality management had just be famous in late $1980 \mathrm{~s}$ and 1990 ISO hijack and redefined it. In fact, there is no universal agreement about the definition of total quality management because different scholars defined it as how they perceived it. It is structured approach to overall organizational management which targeting the quality of organization output. Total quality management is regarded as a customer- organizational culture aims for perfect business operations. It makes sure that all the employees work towards collective goals for the improvement of service quality (Sadikoglu \& Olcay, 2014).

As total quality management important in the attaining organizational objectives to improve the quality of goods produce for customers (Jaca \& Psomas, 2015; Bazazo, Alansari, Alquraan, Alzgaybh \& Masa'deh, 2017). Total quality management is one of the best and suitable approach used by many organizations. Total quality management is one of the popular management concepts around the world. Due to inability to define total quality management, it become difficulty to give vivid meaning. The most accepted definitions of total quality management were the one given by quality experts (Juran, 1981; Deming, 1986; Crosby, 1979; Feigenbaum, 1951). For instance, total quality management has been defined as a management approach for improving organizational performance that encompasses a variety of both technical and behavioral topics (Rahman, \& Mohd Yusof, 2006). Also, total quality management is a holistic management philosophy that strives for continuous improvement in all functions of an organization, and it can be achieved (Kaynak, 2003, Akgün, Ince, Imamoglu, Keskin \& organizational culture (oglu, 2014; Cho, Jung \& Linderman, 2017).

More so, total quality management is view by an organizational as integration of all organizational culture. It affirmed that organization must continue to increase and improve some of these organizational culture by integrating the experience and skills of employees (Chaudary, Zafar \& Salman, 2015; Aminbeidokhti, Jamshidi, \& Mohammadi Hoseini, 2016). One of the common objectives of total quality management is that do the right things, right the first time, every time. Although total 
quality management has been the term used in manufacturing operation but scholars in the management borrow the notion. Apparently, total quality management is has become generic in the field of management tool which has been used in public sector and service organization (Chao, Hsu, Hung, Lin \& Liou, 2015; Reddy, Reddy \& Takhelmayum, 2017).

\section{Organizational Culture Defined}

Organization culture is one the building block of organizational culture of successful organization today. Organizational culture involves values and behavior that leads to the psychological and organizational culture atmosphere of an organization (Dhar, 2015, Hamidizadeh \& Sanavi Fard, 2016). It represents the shared beliefs and values of an organization and can be connected with product of management styles and strategy. In fact, the values have positive effect on employees' behavior as well performance of organization (Ozçelik, Aybas \& Uyargil, 2016). Organizational culture become popular in 1980 when Peter and Waterman produced a book called "in search of excellence". This make the scholars to popularized organization culture and management continue to build on it. The culture of an organization is invisible because it cannot be seen vividly. This make it to affects the thinking, behavioral pattern and behavior as well. Therefore, it fundamental for any organization to internalized organizational culture that will make them retain their position in the market (Habib, Aslam, Hussain, Yasmeen \& Ibrahim, 2014; Hamidizadeh \& Sanavi Fard, 2016).

More so, organizational culture is the pattern of basic assumptions that a group has invented or discovered in learning to cope with its problems of external adaptation and internal integration, and that have worked well enough to be considered valid (Schein, 2004, Helmig, Hinz \& Ingerfurth, 2015). He stressed further that culture is something that dynamic in mature which comes from interaction of one another. Again, organizational culture is a set of values, symbols and rituals, shared by the members of a specific firm, which describes the way things are done in an organization in order to solve both internal management problems and those related to customers, suppliers and environment (Claver, Llopis, González and Gasco, 2001; Yogamalar \& Samuel, 2016).

\section{Concept of Secondary School Performance (SSP)}

Secondary School performance has been coming a topical issue in United Arab Emirate and researchers across the world. The school performance is how well the school is able to achieve the stated aims and objectives. Again, the quality of teachers, instructional materials, level of discipline, the rate students' progress determine the success of schools. As school performance pave way for students' success, Kerawalla and Pandya (1996) holistically defined school performance as the contribution the school made on the students' educational performance in the area of academic achievement. 
Further, school performance is how well students achieve the learning outcome (Reid, Hopkins \& Holly, 1987; Smith, Hoy \& Sweetland, 2014). Effective school performance is when school pass the goals to the students (Clara, 1994). Similarly, school performance is a school where all their students continually experience success at all level (Smith, Hoy \& Sweetland, 2014).

The Relationship between Total Quality Management and School Performance

As mentioned in previous discussion, total quality management is the mechanism to which schools can produce quality output (students). Numerous studies have investigated the relationship between total quality management and organizational performance. For the relationship between total quality management and secondary school performance, Joiner (2007) examined total quality management and performance in Australia. The findings of the study revealed positive relationship between total quality management and organizational performance with $(p, 0.01)$, and total quality management variable increases the $\mathrm{R} 2$ by 0.09 . In the same vein, $\mathrm{Al}$ Damen (2017) examine the impact of total quality management on organizational performance Case of Jordan Oil Petroleum Company using simple random sampling to select 128 managers. The findings revealed that total quality management lead to effective performance of an organization with $\mathrm{df}=9$, mean square $=2.193, f=7.703$, Sig $=.000$.

Also, Habib et al. (2014) investigated the impact of organizational culture on job satisfaction, employees' commitment and turn over intention. The findings of the study revealed that the value of level of significance for Organizational Culture was .005, the significant value of Employees Commitment, Employees Satisfaction and Turnover intention was 0.00 . So $(0.00<0.01)$ which means there is positive relationship between job Satisfaction and its dependent variables. Above all, total quality management determine effective organizational performance. The more the total quality management improve the more the organizational performance would improve.

\section{Methodology}

\section{Population and Sampling}

The population of the study were the employees of all secondary established by the UAE government. The researcher chooses this population because they in the best position to answer questions on total quality management. The total number of staffs according to (MOE, 2019) was 1983 employees in secondary schools and total number of schools was 28. The employees in secondary schools comprised of principal, Vice Principal, HOD and teachers, (ADEK, 2017). Having identified the sample of the study, 320 employees were needed based on the number of populations 1983 using Krejcie and Morgan (1970) sample size table. To get the accurate number without bias, the schools was first stratified into stratum. When the schools were stratum, the quota sampling method was applied. $16.1 \%$ was the quota given to all 
the schools selected. Therefore, 320 employees were used for the final exercise of the study.

\section{Instrumentation}

In order to develop research instrument for this current study, the researcher has endeavor to adapt some items from notable scholars in the field of total quality management, organizational culture as well as secondary school performance. The total quality management practices was adapted from Donmez \& Toker, 2017; Prajogo \& Sohal 2006); Kum, Cowden \& Karodia, 2014, Sadikoglu \& Olcay, 2014. The organizational culture was adapted from Driskell, Salas, \& Hughes, 2010; Bruno (2009); Ramirez, 2012; Ratsameemonthon, 2015; Bruno, 2009; Fine, Van Rooij, Feldman, Shalvi, Scheper, Leib, \& Cauffman 2016. While the secondary school performance was adapted from Stephen, 2016; Anticevic, Kardum, Klarin, Sindik, \& Barač, 2018; Lucky, 2001. The part A was total quality management with five dimensions (school leadership, 5 items), students focus, 5 items), training, 5 items), Knowledge and process management, 5 items) and strategic quality planning, 5 items) respectively. For the section $B$ which organizational culture also had four dimensions like team orientation (5 items), communication (5 items), goal orientation (5 items) and rules orientation (5 items). Section C which was secondary school performance had two dimensions. Students' achievement (5 items) and graduation rate (5 items) based on five Likert-scale.

\section{Findings}

\section{Testing for Reliability}

The study subjected 11 dimensions to reliability test so as to know the suitability for further analysis. Total quality management practices had 5 dimensions, for the dimension measuring total quality management, school leadership has Cronbach alpha of .90; students focus .89; training .81; knowledge and process management .89 and strategic quality planning .90. For organizational culture dimensions, team orientation .89 , communication .82; goal orientation .80 and rules orientation .77 . Also, secondary school performance dimensions, student's achievement .88 and graduation rate .91. Refer to Table 1 . Based on the result, all the 11 constructs met the acceptable value of $>.6$. Therefore, further analysis can be performed on the constructs as well as items.

Table1. Scores of reliabilities for all the variables

\begin{tabular}{lll}
\hline Scale/Item & Cronbach's Alpha & $\begin{array}{l}\text { No } \\
\text { items }\end{array}$
\end{tabular}

Total Quality Management Practices Dimensions

$\begin{array}{lll}\text { School leadership } & .901 & 5 \\ \text { Students focus } & .890 & 5\end{array}$


Training

Knowledge and process management

Strategic quality planning
.811

.894

.905

\section{5}

5

Organizational culture Dimensions

\begin{tabular}{lcc}
\hline Team orientation & .890 & 5 \\
Communication & .821 & 5 \\
Goal orientation & .803 & 5 \\
Rules orientation & .775 & 5 \\
\hline Secondary school Performance Dimensions & & \\
\hline Students' Achievement & .881 & 5 \\
Graduation rate & .911 & 5 \\
\hline
\end{tabular}

\section{Confirmatory Factor Analysis}

Structural equation modeling was used to determine the relationship among total quality management, organizational culture and secondary school performance with the help of AMOS. CFA was also used to test measurement model for all constructs. Some of the items in the model indicated that the data fit the model and loadings have met acceptable value of greater than .5 (Hair et al., 2010). The goodness of fits used for the CFA were comparative fit index (CFI), the root mean square error of approximation (RMSEA), the Tucker-Lewis Index (TLI), the CMIN/DF. The results of CFA for total quality management, organizational culture and secondary school performance were explained in below discussion. See Figure 2, 3 and 4.

\section{The Results of Measurement Model of Total Quality Management}

The confirmatory factor analysis was running to examine the total quality management constructs (dimensions) which contains school leadership, students focus, training, knowledge and process management and strategic quality planning. When all these are subjected to CFA, it was discovered that all the items in the model have strong and acceptable loading of above .60. This indicated that the data fit the model. There was no need to re-specify the model since all the factors loadings have met acceptable value of greater than .5 (Hair et al., 2010). 


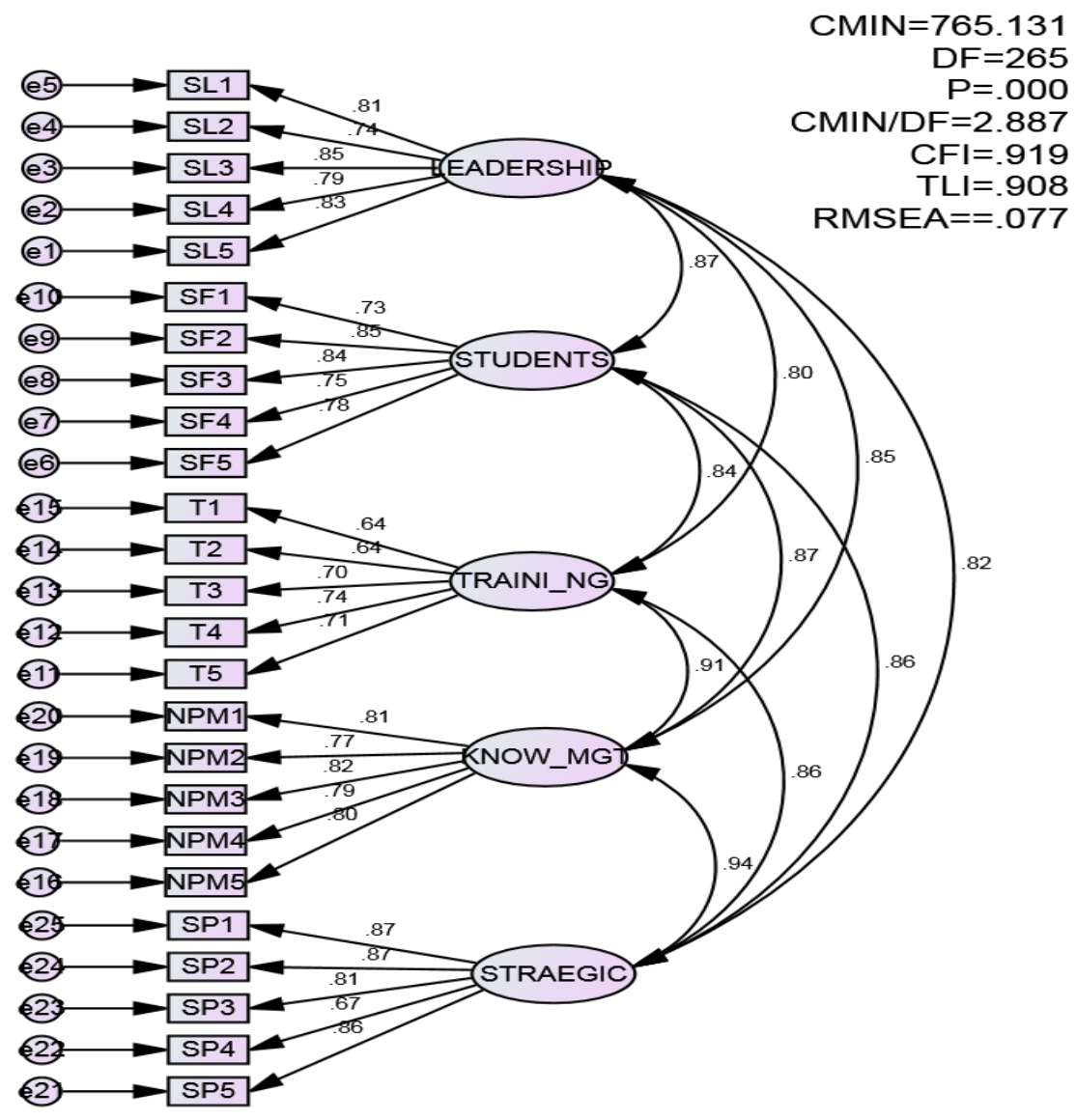

Figure 2. First Measurement Model for Total Quality Management

The results of CFA performed for total quality management dimensions in Figure 2 were $\quad \mathrm{CMIN}=765.131 ; \quad \mathrm{DF}=265 ; \mathrm{P}=.000 ; \quad \mathrm{CMIN} / \mathrm{DF}=2.887$ below maximum requirement value of .5; $\mathrm{CFI}=.919$ met acceptable value of .9; $\mathrm{TLI}=.908$ met acceptable of .9; NFI=.881 and RMSEA=.077. This indicated that the data fit the model. There was no need to re-specify the model since all the factors loadings have met acceptable value of greater than .5 (Hair et al., 2010). This indicated that data fit the model and the data can be used for further analysis.

\section{The Results of Measurement Model of Organizational Culture}

The researcher developed dimensions for measuring organizational culture with constructs towards secondary school academic performance. Namely, team orientation; communication; goals orientation and rules orientation. The total items 
used for organizational culture were 20 items and 4 constructs. The first confirmatory factor analysis was running with the 4 constructs. Some small loadings were deleted and redundant items (E4 and E5, E13 and E14) were correlated as well (Awang, 2012). See Figure 3.

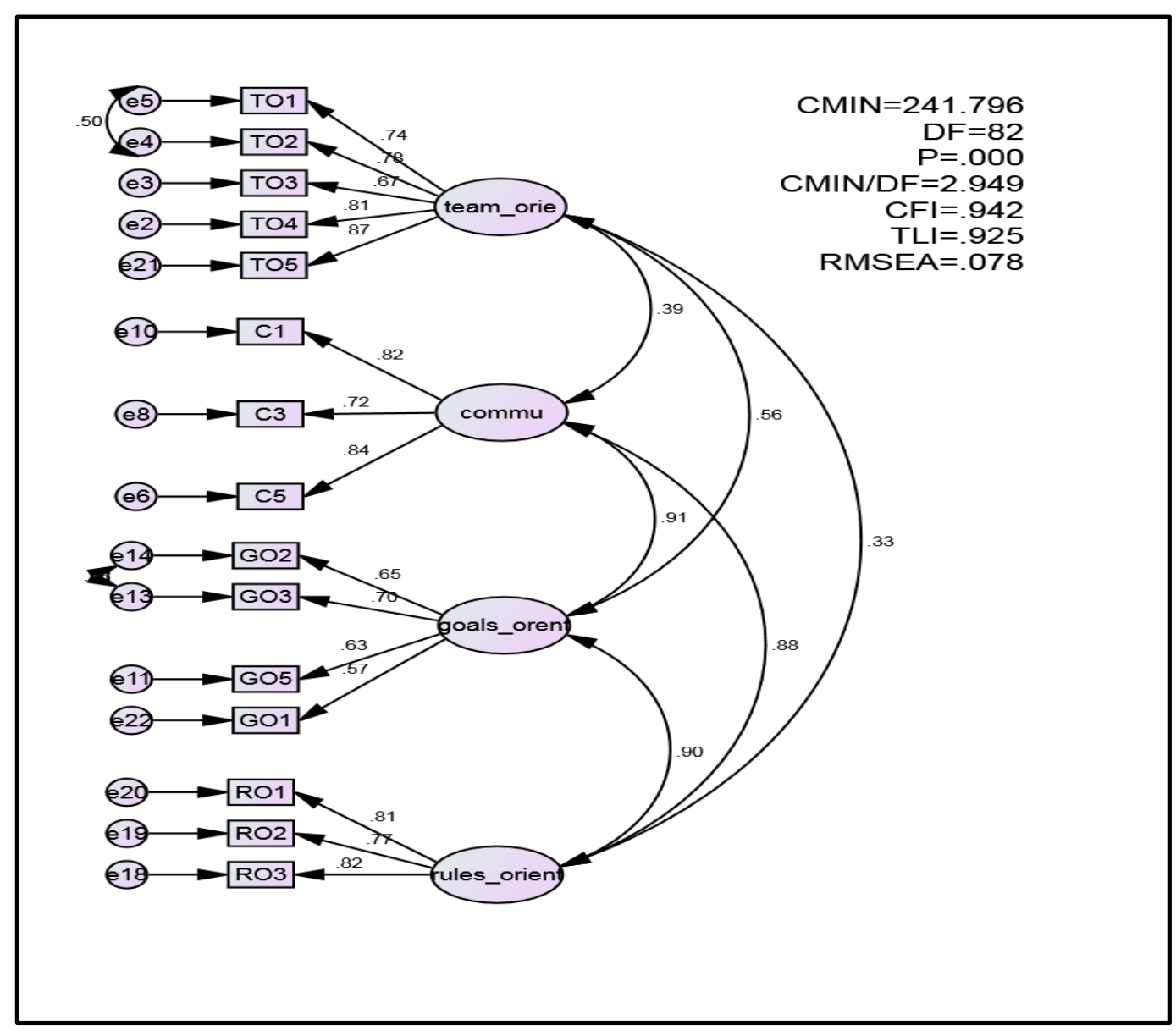

Figure 3. First Measurement Model for Organizational Culture

The results of measurement model/CFA for Figure 3 were $C M I N=241.796, D F=82$, $\mathrm{P}=.000, \mathrm{CMIN} / \mathrm{DF}=2.949, \mathrm{CFI}=.942, \mathrm{TLI}=.925$ and $\mathrm{RMSEA}=.078$. All the fitness indexes met acceptable value of greater .9. All the results of fitness model were above .9 as suggested by Hair et al. (2010). This indicated that data fit the model and the data can be used for further analysis such as structural equation model.

\section{The Results of Measurement Model of Secondary}

The final confirmatory factor analysis was applied to determine good fit of secondary school performance. There were two constructs used for measuring secondary school performance which includes students' achievement and graduation rate. When the 
first confirmatory factor analysis was running with the two constructs. The fitness indexes were met due to and they met acceptable values. The results of measurement model were $\mathrm{CMIN}=59.324, \mathrm{DF}=34, \mathrm{P}=.000, \mathrm{CMIN} / \mathrm{DF}=1.745, \mathrm{CFI}=.957, \mathrm{TLI}=.931$ and RMSEA $=.048$. All the fitness indexes met acceptable value of greater .9. See Figure 4 for the result of measurement model.

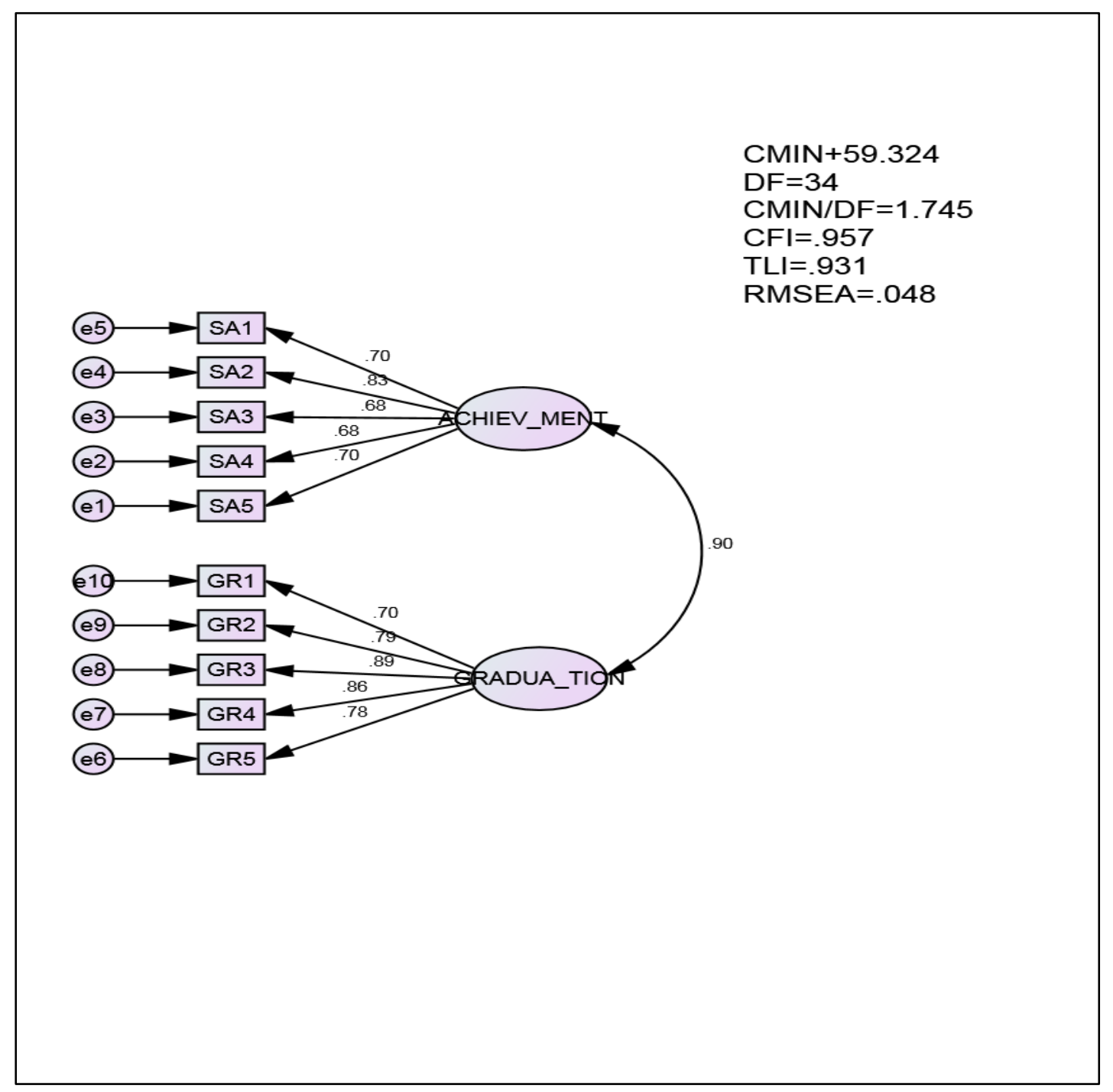

Figure 4. First Measurement Model for Secondary School Performance

\section{The Structural Equation Modeling}

Complete mediation was found because when the mediator (organizational culture) entered the relationship, the direct effect of total quality management on secondary school performance is no longer significant. This indicated that total quality 
management has an indirect effect on secondary school performance through the organizational culture. Complete mediation can also be determining in these ways: The indirect effect $=0.86 \times 0.87=0.7482$ while direct effect $=0-.0$. Both indirect path organizational culture to total quality management $(0.862)$ and organization culture to secondary school Performance (0.872) are significant; since indirect effect > direct effect, the mediation organizational culture; such mediation is called Complete Mediation since direct effect is not significant after organizational culture enters the model. Figure 5 shows the structural equation modeling for the direct effect and causal effect.

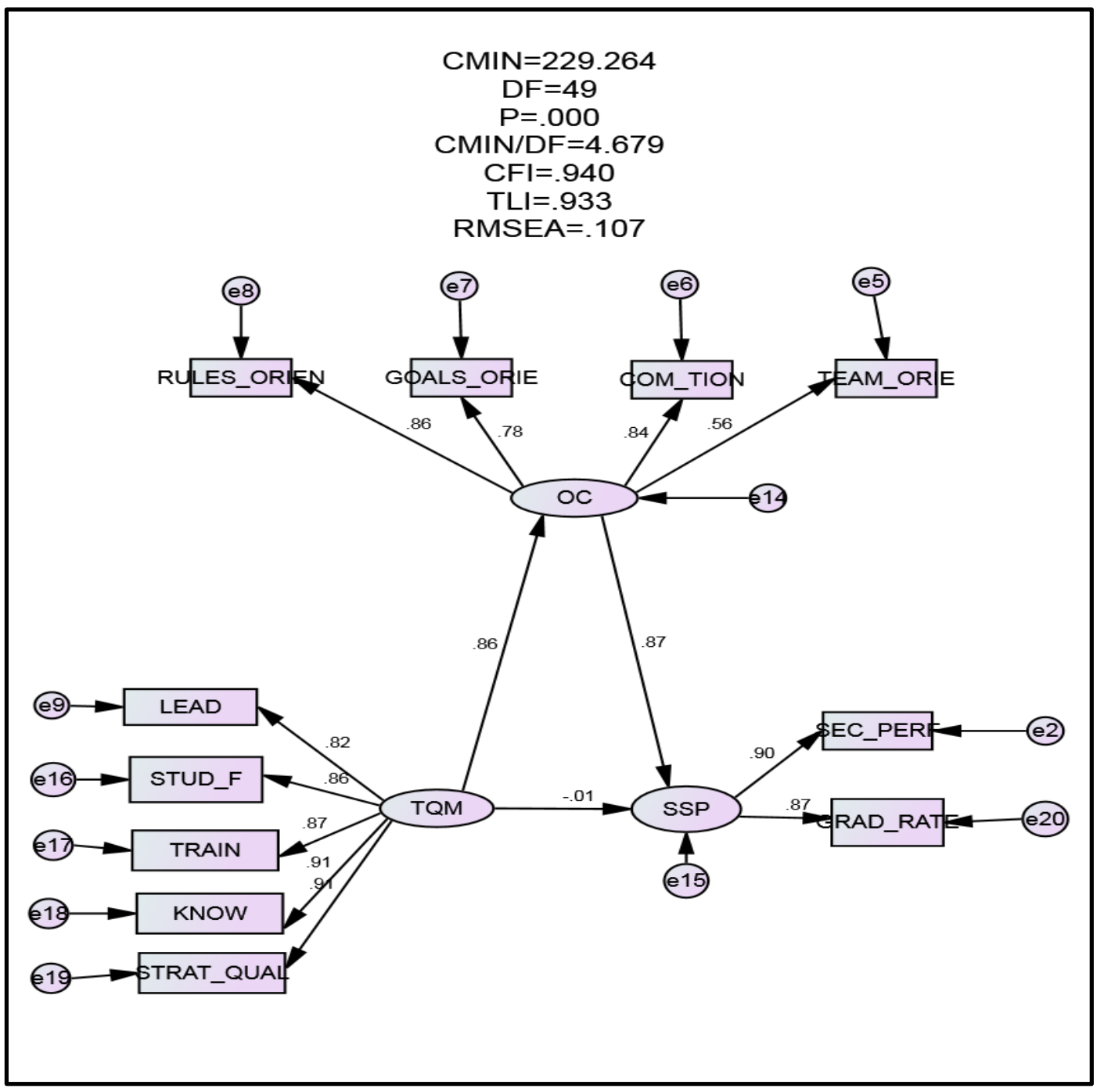

Figure 5. Mediating role of organizational culture on the relationship between total quality management and secondary school performance 
Table 2 of this study showed the standardized regression weights of direct effect and causal effect of the constructs used. The direct effect of total quality management and secondary school performance had the value of 0-.010 which mean the value was not significant. Then, organizational culture and total quality management has the value of 0.862 which indicates significant while the causal effect between secondary school performance and organizational culture also significant with the value of 0.872 . See Table 2 for more explanation.

Table 2. Standardized Regression Weights

\begin{tabular}{|c|c|c|c|c|c|}
\hline Constructs & Path & Constructs & $\begin{array}{l}\text { Beta } \\
\text { Estimate }\end{array}$ & $\begin{array}{l}\text { P- } \\
\text { value }\end{array}$ & Result \\
\hline $\begin{array}{l}\text { Secondary School } \\
\text { Performance }\end{array}$ & $\begin{array}{l}\text { Direct } \\
\text { effect }\end{array}$ & $\begin{array}{l}\text { Total Quality } \\
\text { Management }\end{array}$ & $0-.010$ & 0.105 & Not significant \\
\hline $\begin{array}{l}\text { Organizational } \\
\text { Culture } \\
\text { (Mediator) }\end{array}$ & $\begin{array}{l}\text { Causal } \\
\text { effect }\end{array}$ & $\begin{array}{l}\text { Total Quality } \\
\text { Management }\end{array}$ & 0.862 & 0.001 & Significant \\
\hline $\begin{array}{l}\text { Secondary School } \\
\text { Performance }\end{array}$ & $\begin{array}{l}\text { Causal } \\
\text { effect }\end{array}$ & $\begin{array}{l}\text { Organizational } \\
\text { Culture } \\
\text { (Mediator) }\end{array}$ & 0.872 & 0.001 & Significant \\
\hline
\end{tabular}

\section{Summary of Results of Hypotheses Testing}

The summary of hypotheses testing results were shown in table 4 and all the hypotheses formulated were significant. The summary of the hypotheses stated that; significant relationship exists between total quality management and secondary school performance; significant relationship exist between total quality management and organizational culture in secondary schools. Also, significant relationship exist between organizational culture and secondary school performance; and organizational culture mediate the relationship between total quality management and secondary school performance. See table 3.

Table 3. Synopsis of results of hypotheses testing for h1-H4

Hypotheses

H1 There will be significant relationship between total quality management and secondary school performance

H2 There will be significant relationship between total quality management and organizational culture in secondary schools

H3 There will be significant relationship between organizational Significant

H3 There will be significant relationship betwee
culture and secondary school performance

\section{Results}

Not

Significant

Significant 
H4 There will be mediating role of organizational culture on the relationship between total quality management and secondary

Complete school performance

Mediation

\section{Discussion}

This study tested the relationship between total quality management (total quality management) and secondary school performance. The regression weight result showed, total quality management has a significant effect on secondary school performance with 0.74. Based on the finding discussion, Scholars such as Jaca and Psomas, (2015); Bazazo, Alansari, Alquraan, Alzgaybh and Masa'deh (2017) jointly agreed with these findings that total quality management is important school in the attaining organizational objectives to improve the quality of services render for students. Similarly, Rahman (2005) corroborated with is result that total quality management has been adopted by school from field of management for improving organizational performance that encompasses a variety of both technical and behavioral topics.

In another development, the findings of this study were supported by Hendricks and Singhal (2001) that total quality management in organizational help to develop a conducive climate in which an organization continuously improve and deliver high quality product that will meet the satisfaction of customers. In the same manner, Sadikoglu and Olcay (2014) agreed that total quality management is regarded as a customer focus which aims for perfect business operations. Quality should focus organizational culture on the requirement and specification of the students. When students get quality requirement from the school, school would be counted themselves as part of performing schools.

The study also tested the direct relationship between total quality management (total quality management) and organizational culture (organizational culture) with used of SEM analysis. Based on regression weight results of total quality management on organizational culture which indicated 0.86. As expressed by Dhar (2015) and Hamidizadeh and Sanavi Fard (2016) that organization culture is the building of successful organization. It is organizational culture that involves values and behavior that leads to the psychological and organizational culture atmosphere of an organization. Based on this findings, Panuwatwanich and Nguyen (2017) supported this finding that effective utilization of total quality management in organization can lead to organizational culture, that these two concepts cannot be separated.

In the same vein, the findings of Alghamdi (2018) on total quality management on organizational culture which revealed that total quality management and organizational culture has cordial relationship. The finding revealed by Alghamdi (2018) was in line with this current finding that interaction of total quality management and organizational culture could have positive relationship with 
organizational performance. in the same note, Elassy (2015); Ali (2017); Arditi, Nayak \& Damci (2017) jointly contributed to this current finding that total quality management and organizational culture can leads into effective school performance and these two variables are essential for the growth of any organization that intend to quality services. On this finding of this study, Ngambi and Nkemkiafu (2015) reported that understanding of total quality management and organizational culture in a school environment would determine how the aims and objectives can be achieved.

More so, the relationship between organizational culture and secondary school performance were tested using structural equation modeling. The result of regression weight indicated 0.87 for direct relationship between organizational culture and SSP. this hypothesis was supported based on the hypothesis formulated that there will be significant relationship between organizational CULTURE and SSP The result of this study was in line with assertion made by Ozçelik, Aybas and Uyargil (2016) that core values that established in a school system usually positive effect on teachers' behavior. Also, the findings of Hamidizadeh and Sanavi Fard (2016) on organizational culture supported this finding that it is fundamental for any school to internalized organizational culture that would make them retain their position in the performing schools.

More so, as organizational culture defined by Mueller (2014) as collective values and beliefs that inform teachers in the school about what is moral and immoral. As a result of this noble definition, Belias and Koustelios (2014) buttressed this finding that organizational culture is a product of a group of people to stay together and having the same behavior and attitude. On the same opinion on this finding, Xenikou and Furnham (1996) supported with four types of organizational culture that is applicable to schools. First, the competition and confrontation culture that any organization with type are goal oriented and highly competitive. Second, the bureaucratic culture which means conservative and employees are characterized by centralized decision making. Third, task-oriented culture means that the organizational culture on quality of product or services to be render. Lastly, the openness to change/ innovation culture which refers to human oriented that organizational culture on task support, achievement, task innovation and self-actualization. With this contribution, it is important for school management to established organization culture in the system so that the quality education would be provided to the students.

\section{Recommendations}

The policy makers and school head should endeavor to send teachers for professional development so that their productivity could be improve in the school.

Again, as teachers' part of transformation in the educational setting, the policy maker and school heads should improve and inculcate the spirit of total quality management and organizational culture so that quality would be produce continuously. 
In the same, incentives, increment in salary and promotion are the cardinal factors that make teachers to increase their services in the school.

The study recommend that organizational culture should be dictated to teacher working in the school. This is because, when teacher know the culture of the school, they will be able to discharge their duties effectively.

\section{Conclusion}

Total quality plays a wonderful role in the provision of quality students. Teachers has been noted as an agent of quality transformational. Hence, the five dimensions of total quality management and four dimensions of organizational culture are needed in secondary school and it must be used by the school heads in order to produce quality output in the country. As a matter of fact, total quality management serve as predictor of quality education in the country. As total quality management important in the attaining organizational objectives to improve the quality of students. Total quality management is one of the best and suitable approach used by many organizations.

\section{References}

[1] Akgün, A. E., Ince, H., Imamoglu, S. Z., Keskin, H., \& Korganizational cultureoglu, İ. (2014). The mediator role of learning capability and business innovativeness between total quality management and financial performance. International Journal of Production Research, 52(3), 888-901.

[2] Akhtar, S., Zameer, H., \& Saeed, R. (2014). Impact of Total Quality Management on the Performance of Service Organizations in Pakistan. International Journal of Academic Research in Economics and Management Sciences, 3(6), 109.

[3] Alghamdi, F. (2018). Total quality management and organizational performance: A possible role of organizational culture. International Journal of Business Administration, 9(4), 186-200.

[4] Ali, A. (2017). Cultural intelligence and leadership style in the education sector. International Journal of Educational Management, 31(6), 718-735.

[5] Aminbeidokhti, A., Jamshidi, L., \& Mohammadi Hoseini, A. (2016). The effect of the total quality management on organizational innovation in higher education mediated by organizational learning. Studies in Higher Education, 41(7), 1153-1166.

[6] Arditi, D., Nayak, S., \& Damci, A. (2017). Effect of organizational culture on delay in construction. International Journal of Project Management, 35(2), 136-147.

[7] Arditi, D., Nayak, S., \& Damci, A. (2017). Effect of organizational culture on delay in construction. International Journal of Project Management, 35(2), 136-147.

[8] Bazazo, I., Alansari, I., Alquraan, H., Alzgaybh, Y., \& Masa'deh, R. E. (2017). The influence of total quality management, market orientation and e-marketing on Hotel performance. International Journal of Business Administration, 8(4), 79- 82. 
[9] Belias, D., \& Koustelios, A. (2014). Organizational culture and job satisfaction: A review. International Review of Management and Marketing, 4(2), 132-149.

[10] Belias, D., \& Koustelios, A. (2014). Organizational culture and job satisfaction: A review. International Review of Management and Marketing, 4(2), 132-149.

[11] Chao, C. Y., Hsu, H. M., Hung, F. C., Lin, K. H., \& Liou, J. W. (2015). Total quality management and human resources selection: A case study of the national teacher selection in Taiwan. Total Quality Management \& Business Excellence, 26(1-2), 157-172.

[12] Cho, Y. S., Jung, J. Y., \& Linderman, K. (2017). The QM evolution: Behavioral quality management as a firm's strategic resource. International Journal of Production Economics, 191, 233-249.

[13] Claver, E., Llopis, J., González, M.R., Gasco, J.L. (2001). The performance of information systems through organizational culture. Information Technology \& People, 14(3), 247-260.

[14] Crosby, Philip (1979). Quality is free. New York: McGraw-Hill.

[15] Dhar, R. L. (2015). Service quality and the training of employees: The mediating role of organizational commitment. Tourism Management, 46, 419430.

[16] Elassy, N. (2015). The concepts of quality, quality assurance and quality enhancement. Quality Assurance in Education, 23(3), 250-261.

[17] Gharakhani, D., Rahmati, H., Farrokhi, M. R., \& Farahmandian, A. (2013). Total quality management and organizational performance. American Journal of Industrial Engineering, 1(3), 46-50

[18] Habib, S., Aslam, S., Hussain, A., Yasmeen, S., \& Ibrahim, M. (2014). The impact of organizational culture on job satisfaction, employess commitment and turn over intention. Advances in Economics and Business, 2(6), 215-222.

[19] Hamidizadeh, A., \& Sanavi Fard, R. (2016). Effect of employee branding on market share based on individual and organizational values (Studied in: Mellat Bank). Iranian Journal of Management Studies, 9(3), 505-527.

[20] Helmig, B., Hinz, V., \& Ingerfurth, S. (2015). Valuing organizational values: Assessing the uniqueness of nonprofit values. International Journal of Voluntary and Nonprofit Organizations, 26(6), 2554-2580.

[21] Hendricks, K. B., \& Singhal, V. R. (2001). Firm characteristics, total quality management, and financial performance. Journal of Operations Management, 19(3), 269-285.

[22] Jaca, C., \& Psomas, E. (2015). Total quality management practices and performance outcomes in Spanish service companies. Total Quality Management \& Business Excellence, 26(9-10), 958-970.

[23] Mahmood, S., Qadeer, F., \& Ahmed, A. (2015). The role of organizational learning in understanding relationship between total quality management and organizational performance. Pakistan Journal of Commerce and Sorganizational cultureial Sciences, 9(1), 282-302. 
[24] Mueller, R. A. (2014). A general model of organizational values in educational administration. Educational Management Administration \& Leadership, 42(5), 640-656.

[25] Ngambi, M. T., \& Nkemkiafu, A. G. (2015). The impact of total quality management on firm's organizational performance. American Journal of Management, 15(4), 69.

[26] Ozçelik, G., Aybas, M., \& Uyargil, C. (2016). High performance work systems and organizational values: Resource-based view considerations. Prorganizational cultureedia-Sorganizational cultureial and Behavioral Sciences, 235, 332-341.

[27] Raimona Zadry, H., \& Mohd Yusof, S. R. (2006). Total quality management and theory of constraints implementation in Malaysian automotive suppliers: a survey result. Total Quality Management, 17(8), 999-1020.

[28] Sadikoglu, E., \& Olcay, H. (2014). The effects of total quality management practices on performance and the reasons of and the barriers to TOTAL QUALITY MANAGEMENT practices in Turkey. Advances in Decision Sciences, 2(1)1-18.

[29] Schein, E.H. (2004). Organizational Culture and Leadership (3rd ed). John Wiley \& Sons, Inc.

[30] Soomro, T. R., \& Ahmad, R. (2012). Quality in higher education: United Arab Emirates perspective. Higher Education Studies, 2(4), 148-152.

[31] Suleman, Q., \& Gul, R. (2015). Challenges to successful total quality management implementation in public secondary schools: A case study of Kohat District, Pakistan. Journal of Education and Practice, 6(15), 123-134.

[32] Yogamalar, I., \& Samuel, A. A. (2016). Shared values and organizational citizenship behavior of generational cohorts: A review and future directions. Management: journal of Contemporary Management Issues, 21(2), 249-271. 